\title{
Nutrient and fatty acid composition of cultured and wild caught gold-spot mullet Liza parsia (Hamilton, 1822)
}

\author{
J. SYAMA DAYAL, K. AMBASANKAR, R. JANNATHULLA, K. P. KUMURAGURUVASAGAM \\ AND M. KAILASAM \\ ICAR-Central Institute of Brackishwater Aquaculture, 75, Santhome High Road, R. A. Puram, Chennai- 600028 \\ Tamil Nadu, India \\ e-mail:syamdayal@rediffmail.com
}

\begin{abstract}
The gold-spot mullet, Liza parsia (Hamilton, 1822) is a common mullet species that constitutes year round thriving fishery in the shallow coastal waters, estuaries, mangrove swamps and brackishwater lakes along the coast of India. Nutrient and fatty acid composition were analysed in cultured and wild caught L. parsia of different size groups. Fish were cultured with formulated pelleted feed in brackishwater pond at Nagayalanka $\left(15.945^{\circ} \mathrm{N} ; 80.918^{\circ} \mathrm{E}\right)$, Andhra Pradesh, India. Wild samples of $L$. parsia were caught from the same region near Krishna River. The fishes were categorised into four size groups $(<50 \mathrm{~g}, 50-100 \mathrm{~g}, 101-150 \mathrm{~g}$ and $>150 \mathrm{~g})$ from both sources. The moisture and ash content were higher $(\mathrm{p}<0.05)$ in wild fishes (75.85 and 1.39\%) compared to cultured ones (72.96 and 1.29\%). Cultured L. parsia had higher ( $<<0.05)$ crude lipid (2.12-8.73\%) across all size groups compared to wild group which recorded crude lipid in the range of $0.67-3.10 \%$. However, no significant change was observed for crude protein between wild and cultured fish. The quantities $\left(\mathrm{mg}^{100 \mathrm{~g}^{-1}}\right.$ of fish muscle) of 18:2n- 6 fatty acids were significantly $(\mathrm{p}<0.05)$ higher by 12 fold in farmed fish, whereas $20: 4 n-6$ was higher $(\mathrm{p}<0.05)$ by two times in captive L. parsia. Significant $(\mathrm{p}<0.05)$ difference was observed in docosahexaenoic acid

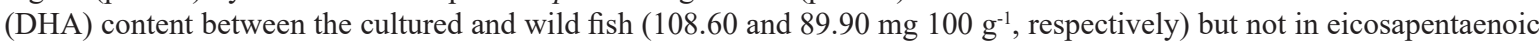
acid (EPA) (110.59 and $115.03 \mathrm{mg} 100 \mathrm{~g}^{-1}$ respectively). The consumption of $100 \mathrm{~g} \mathrm{~L}$. parsia fish which was above $100 \mathrm{~g}$ size of both wild and farmed could meet per day $(250 \mathrm{mg})$ dietary needs of EPA and DHA.
\end{abstract}

Keywords: DHA, EPA, Fatty acids, Liza parsia, Mullet, Nutrients

\section{Introduction}

Seafood is considered as a good source of high-quality nutrients like protein and fatty acids. Globally, fish makes up $17 \%$ of the animal protein intake and the increase in per capita consumption has increased to $19 \mathrm{~kg}$ from $10 \mathrm{~kg}$ in 1960's (FAO, 2014). With stable figures in wild harvest of fish for several decades, total seafood production is steadily increasing due to aquaculture with an estimated share of $42 \%$ of total global fish production in 2012 by weight (FAO, 2014). Aquaculture is nowadays considered as leading contributor to production of quality food which can resolve the global burden related to human disease due to the lack of adequate quality food (FAO, 2014). The potential health benefits related to consumption of fish and fish-derived products are attributed to the presence of eicosapentaenoic acid (EPA), docosahexaenoic acid (DHA), several other essential nutrients and growth factors, which play several key roles in human health (Conor, 2000). These fatty acids in addition to reducing the risk of cardiovascular diseases/cancers, play significant role in several physiological functions in man (Berbert et al., 2005; Calo et al., 2005; Wolk et al., 2006). The
EPA, as a source of prostaglandin $\left(\mathrm{PGI}_{3}\right)$, prevents atherosclerosis and vascular constriction by keeping the vascular walls soft and flexible. Australian researchers identified DHA for preventing cardiac arrhythmia and for improvement of infant neural development (Ackman, 1996). Fish lipids are practically the only source of EPA and DHA for human being. The U. S. Dietary Guidelines recommends consumption of about eight ounces per week of a variety of seafood, which provide an average consumption of $250 \mathrm{mg} \mathrm{day}^{-1}$ of EPA and DHA, for general population to reduce cardiac deaths among individuals with and without pre-existing cardiovascular diseases (USDHHS, 2015).

Nutrient composition varies greatly from species to species, as well as, from individual to individual of the same species due to differences in size, seasons, locations, habitat, gender, age and source of collection i.e., wild or captivity (Krajnovic-Ozretic et al., 1994; Alasalvar et al., 2002; Grigorakis et al., 2002; Fuentes et al., 2010). Wide variations were observed in the quantities of EPA (2.7-2041 mg $\left.100 \mathrm{~g}^{-1}\right)$ and DHA (9-277 mg $\left.100 \mathrm{~g}^{-1}\right)$ in both marine fish and shellfish (Aziz et al., 2013). The crucial 
question arising today is whether the nutritional value particularly in terms of fatty acids of cultured and wild fish is equivalent or superior, which is an important determinant for acceptability of the farmed fish by consumers. The availability of reliable nutritional data base of wild and cultured fish species helps for nutritional labeling and also forms the base for dietary prescriptions by doctors and dieticians. In earlier studies, the fatty acid profiles of wild and farmed fishes were compared in gilthead seabream (Grigorakis et al., 2002) and seabass (Krajnovic-Ozretic et al., 1994; Alasalvar et al., 2002; Fuentes et al., 2010). Nonetheless, majority of the earlier studies reported fatty acids as percentage of total fatty acids. But expressing fatty acid quantity in terms of $\mathrm{mg}$ per $100 \mathrm{~g}$ fish will be of better utility in nutritional labeling and dietary value calculations (Aziz et al., 2013). Similarly, the effects of size and season on nutrient and mineral profiles were earlier reported in Anabas testudineus (Paul et al., 2015).

Mullets have a very wide distribution in all the oceans, estuaries and brackishwaters of tropical and sub-tropical regions (Nash and Shehadeh, 1980; Ramirez et al., 2003). Gold-spot mullet Liza parsia (Hamilton, 1822 ) is a common mullet which constitutes a year round thriving fishery in the shallow coastal waters, estuaries, mangrove swamps and brackishwater lakes in India. This is a euryhaline and eurythermal fish species and it is one of the most favourite, tasty and commercially important fish in South-east Asia, especially in India and many parts of central and South America. The above eurytopic characteristics, together with its foraging habits at the base of the food web, enable this species to be a popular species for aquaculture. Karakoltsidis et al. (1995) and Menezes et al. (2008), reported lipid content of wild mullet Mugil sp. as $1-3 \%$ on wet weight basis. However, to date, there is no report on comparison of nutrient profiles of wild and cultured mullets. Hence in the present study, an attempt was made to quantify and compare the nutrient and fatty acid profiles of pellet fed cultured $v s$ wild caught $L$. parsia of different size groups.

\section{Materials and methods}

\section{Fish samples}

For the analysis of nutrient and fatty acid composition, different size groups of cultured and wild L. parsia were sourced from brackishwater fish farm at Nagayalanka $\left(15.945^{\circ} \mathrm{N} 80.918^{\circ} \mathrm{E}\right.$; Diviseema region) and brackishwater regions of Krishna River, respectively of Krishna District, Andhra Pradesh, India. In the farm, mullets were raised for eight months with pelleted feed having 33.4\% crude protein and $5.7 \%$ ether extract (Dayal et al., 2017). The fish feed was formulated and manufactured at the feed mill of ICAR-Central Institute of Brackishwater Aquaculture
(ICAR-CIBA), Chennai, India. Fish feed in dry pellet form was processed and produced using Ring-Die pellet mill. Briefly, the coarse ingredients were powdered by two stage grinding by hammer mill followed by micropulveriser and passed through $0.5 \mathrm{~mm}$ screen. All the ingredients along with liquid components (fish oil and soy-lecithin) and binder were mixed in a horizontal ribbon mixer and thoroughly homogenised after adding 31 of water per $100 \mathrm{~kg}$. The mash was pelletised in the Ring- Die pellet mill at $15-16 \%$ moisture and temperature of $90^{\circ} \mathrm{C}$ under steam conditioning. The pellets were conditioned, dried, packed and transported to the experimental site.

Salinity of the pond water was in the range of $12-22 \%$. Salinity of the brackishwater regions of Krishna River ranged between 10 and 18\%o (MarchOctober 2014) in the fish sample collection area. Fishes were collected from the farm and wild sources at regular intervals until harvest in such a way to have four size groups $(<50 \mathrm{~g}, 50-100 \mathrm{~g}, 101-150 \mathrm{~g}$ and $>150 \mathrm{~g})$. The fishes were dressed and skin was removed. Boneless muscle tissue, collected from both upper dorsal and lower ventral areas of the fish alone were used for analyses. The muscle samples from each group (5-8 fishes) were pooled together, with three replications for each size group for wild and cultured groups and stored at $-20^{\circ} \mathrm{C}$ until analysis.

\section{Laboratory analysis}

The nutrients composition of fish feed and the fish tissue samples were determined following standard methods of AOAC (1997). Lipid was extracted by the method of Folch et al. (1957) using chloroform and methanol $(2: 1)$ and respective fatty acid methyl esters (FAME) were prepared according to Metcalf et al. (1966). Briefly, the extracted lipids were trans-esterified with $\mathrm{BF} 3-$ methanol and $0.5 \mathrm{~N}$ methanolic sodium hydroxide and finally, FAMEs were extracted into petroleum ether $(2.0 \mathrm{ml})$. Routine analysis of methyl esters was performed by a gas chromatograph (GC-2014 Shimadzu) on a RT $\mathrm{x}$ wax capillary column (100 m length x $0.25 \mathrm{~mm}$ I.D $\mathrm{x} 0.2 \mu \mathrm{m}$ film thickness). Nitrogen was used as carrier gas at a linear velocity of $20.9 \mathrm{~cm} \mathrm{~s}^{-1}$ with $3 \mathrm{ml} \mathrm{min}-1$ of purge flow. The oven temperature was held at $100^{\circ} \mathrm{C}$ for $4 \mathrm{~min}$ and increased to $225^{\circ} \mathrm{C}$ at $3^{\circ} \mathrm{C} \mathrm{min}^{-1}$ and held for $5 \mathrm{~min}$ followed by temperature increase of $1^{\circ} \mathrm{C} \mathrm{min}^{-1}$ to $240^{\circ} \mathrm{C}$ and held for $10 \mathrm{~min}$. Operating temperatures for injection ports and flame ionisation detector were 225 and $250^{\circ} \mathrm{C}$ respectively. Compounds were identified by comparison with retention times of 37 component FAME mix (Supelco-Sigma, USA). The quality of analysis was checked with a blank and a control i.e., menhaden oil. Tridecanoic acid methyl ester (C13:0, Supelco-Sigma, USA) was used as an internal standard to calculate fatty 
acid content in sample (mg $100 \mathrm{~g}^{-1}$ ) as described by Aziz et al. (2013) by calculating the empirical response factor of flame ionization detector.

Fatty acid (mg $\left.100 \mathrm{~g}^{-1}\right)=$ AX x WIS x Ri x 1000/AIS / WX / 1.04

where, $\mathrm{AX}=$ Peak area of fatty acid, AIS $=$ Peak area of internal standard, WIS $=$ Weight of internal standard $(\mathrm{mg}), \mathrm{WX}=$ Sample weight $(\mathrm{g}), \mathrm{Ri}=$ Empirical factor and $1.04=$ Factor to convert FAME to fatty acid.

Empirical factor $=$ Psi $x$ WISm $/$ PsIS $/$ Wi

where, Psi=Peak area of individual fatty acid in a mixed FAME standard solution, PsIS=Peak area of fatty acid internal standard in mixed FAME standard solution, WISm=Weight of fatty acid internal standard in mixed FAME standard solution and $\mathrm{Wi}=$ Weight of individual FAME in mixed FAME standard solution.

\section{Statistical analysis}

The experimental data with two factors viz., source of fish collection (wild and cultured) and size groups (four size groups) with four levels in each factor were analysed using $2 \times 4$ factorial design. The descriptive statistical measures (mean \pm standard error) were calculated for two main factors and their interactions. All data analyses were done using SPSS version 17.0. The post-hoc analysis was done using least significant difference. Comparison of means was carried out at $5 \%$ significance level $(p<0.05)$.

\section{Results and discussion}

The nutrient and fatty acid composition of the feed used for culture of goldspot mullet is presented in Table 1. The feed contained $33.4 ; 5.7 ; 3.8 ; 11.87$ and $37 \%$ crude protein, crude fat (ether extract), crude fibre, total ash and nitrogen free extract respectively. The predominant fatty acids in feed includes palmitic (C16:0), linoleic (C18:2n-6), oleic (C18:1n-9), stearic (C18:0) followed by palmitoleic $(\mathrm{C} 16: 1 \mathrm{n}-7)$ and eicosapentaenoic acids (C20:5n-3). Prior to feed formulation, the fatty acid profiles of the individual feed ingredients were analysed. The proportion of different fatty acids was clearly reflected in the experimental feed which indicates no negative impact on fatty acid composition due to feed processing.

The results of nutrient analysis of different size groups of cultured and wild L. parsia are shown in Table 2. Moisture content was higher $(\mathrm{p}<0.05)$ in wild fishes compared to cultured and an inverse relationship was observed with the total lipid content. Cultured L. parsia had higher $(\mathrm{p}<0.05)$ crude lipid values across all size groups. The effect of size was conspicuous in lipid values and the lipid values increased proportionately with size of the fish $(\mathrm{p}<0.05)$ in both wild and cultured fishes. The result is in agreement with our earlier study (Dayal
Table 1. Proximate and fatty acid composition of the feed used for the culture of $L$. parsia in brackishwater pond

\begin{tabular}{ll}
\hline Particulars & \\
\hline Proximate composition (\% fed basis) & \\
Moisture & 8.23 \\
Crude protein & 33.4 \\
Ether extract & 5.70 \\
Crude fibre & 3.80 \\
Nitrogen free extract ${ }^{1}$ & 37.00 \\
Total ash & 11.87 \\
\hline Fatty acid composition (mg $100 \mathrm{~g}^{-1}$ total fatty acids) & \\
\hline C14:0 & \\
C15:0 & 234.61 \\
C16:0 & 24.65 \\
C17:0 & 1182.08 \\
C18:0 & 76.14 \\
C23:0 & 272.32 \\
C14:1 & 74.32 \\
C16:1 & 32.49 \\
C18:1c & 719.55 \\
C18:2c & 627.44 \\
C18:3n-6 $18: 3 n-3$ & 1051.28 \\
C20:4 n-6 $620: 5 \mathrm{n}-3$ & 117.04 \\
C22:6 n-3 & 66.17 \\
\hline
\end{tabular}

${ }^{1}$ Calculated by difference

et al., 2017) where the whole body (except head and tail) composition of both cultured and wild collected L. parsia and $M$. cephalus were compared. The interactions of source of fish and sizes were also significantly different $(\mathrm{p}<0.05)$. The lipid content of wild L. parsia was similar to the level found in other mullet species i.e., Mugil sp. (Karakoltsidis et al., 1995; Menezes et al., 2008). Based on their estimates, Marais and Erasmus (1977) rated mugilids as 'fatty fish' which is also appropriate for farmed L. parsia in the present study. Higher lipid content in farmed $L$. parsia could mainly be attributed to the type of food consumed by the fish. Compared to the natural feeds such as algae and detritus consumed by wild fishes, formulated pellets offered to the farmed fishes were nutrient dense. Grigorakis et al. (2002) observed a similar situation of fat accumulation in farmed fish and they attributed this to energy consumption in the form of dietary carbohydrates and reduced activity (Alasalvar et al., 2002) compared to wild fish which were also prone to periods of starvation (Haard, 1992). These results also corroborate the findings of other workers who compared captive and farmed fishes (George and Bophal 1995; Grigorakis et al., 2002; Zhao et al., 2010).

A direct positive relationship in total lipid and size of the fish irrespective of the source and feeding history of 
Table 2. Body composition (\% wet weight basis) of $L$. parsia of different size groups collected from wild and captivity

\begin{tabular}{|c|c|c|c|c|}
\hline \multirow{2}{*}{ Particulars } & \multicolumn{4}{|c|}{ Body composition } \\
\hline & Moisture & $\mathrm{CP}$ & $\mathrm{EE}$ & Total Ash \\
\hline \multicolumn{5}{|l|}{ Source } \\
\hline Cultured & $72.96^{\mathrm{b}} \pm 0.89$ & $19.00 \pm 0.25$ & $4.84^{\mathrm{a}} \pm 0.80$ & $1.29^{\mathrm{b}} \pm 0.04$ \\
\hline Wild & $75.85^{\mathrm{a}} \pm 0.50$ & $20.00 \pm 0.38$ & $1.71^{\mathrm{b}} \pm 0.28$ & $1.39^{\mathrm{a}} \pm 0.04$ \\
\hline \multicolumn{5}{|l|}{ Size groups $(\mathrm{g})$} \\
\hline$<50$ & $76.52^{\mathrm{a}} \pm 0.63$ & $19.91 \pm 0.30$ & $1.40^{\mathrm{d}} \pm 0.41$ & $1.21^{\mathrm{b}} \pm 0.05$ \\
\hline $50-100$ & $75.85^{\mathrm{a}} \pm 0.29$ & $19.50 \pm 0.49$ & $2.14^{\mathrm{c}} \pm 0.34$ & $1.42^{\mathrm{a}} \pm 0.03$ \\
\hline $101-150$ & $74.20^{\mathrm{b}} \pm 0.99$ & $19.14 \pm 0.56$ & $3.66^{\mathrm{b}} \pm 0.90$ & $1.34^{\mathrm{ab}} \pm 0.05$ \\
\hline$>150$ & $71.05^{\mathrm{c}} \pm 1.12$ & $19.50 \pm 0.60$ & $5.92^{\mathrm{a}} \pm 1.27$ & $1.40^{\mathrm{a}} \pm 0.07$ \\
\hline \multicolumn{5}{|c|}{ Source x Size $(\mathrm{g})$ interactions } \\
\hline Cultured $\mathrm{x}<50$ & $75.50^{\mathrm{b}} \pm 0.96$ & $19.90 \pm 0.64$ & $2.12^{\mathrm{de}} \pm 0.57$ & $1.19 \pm 0.09$ \\
\hline Cultured x 50-100 & $75.46^{b} \pm 0.38$ & $18.60 \pm 0.56$ & $2.87^{\mathrm{cd}} \pm 0.11$ & $1.41 \pm 0.03$ \\
\hline Cultured $\mathrm{x}<101-150$ & $72.26^{c} \pm 0.59$ & $18.78 \pm 0.26$ & $5.65^{\mathrm{b}} \pm 0.25$ & $1.28 \pm 0.09$ \\
\hline Cultured $x>150$ & $68.61^{\mathrm{d}} \pm 0.14$ & $18.74 \pm 0.18$ & $8.73^{\mathrm{a}} \pm 0.30$ & $1.27 \pm 0.03$ \\
\hline Wild $x<50$ & $77.53^{\mathrm{a}} \pm 0.04$ & $19.92 \pm 0.25$ & $0.67^{\mathrm{f}} \pm 0.02$ & $1.22 \pm 0.08$ \\
\hline Wild x 50-100 & $76.24^{\mathrm{ab}} \pm 0.36$ & $20.40 \pm 0.32$ & $1.40^{\mathrm{ef}} \pm 0.09$ & $1.43 \pm 0.06$ \\
\hline Wild $x<101-150$ & $76.14^{\mathrm{ab}} \pm 0.90$ & $19.51 \pm 1.18$ & $1.68^{\mathrm{e}} \pm 0.16$ & $1.40 \pm 0.02$ \\
\hline Wild $x>150$ & $73.49^{c} \pm 0.57$ & $20.15 \pm 1.15$ & $3.10^{c} \pm 0.31$ & $1.52 \pm 0.07$ \\
\hline
\end{tabular}

All values are mean $\pm \mathrm{SE}$ of three replications

Means bearing same superscripts in a column within the category do not differ significantly $(\mathrm{p}>0.05)$

the fish indicates that this intrinsic physiological property may be related to the reproductive physiology of this fish (Rheman et al., 2002). Similar observations have been reported in seabass and gilthead seabream (Poli et al., 2001; Grigorakis and Alexis, 2005). Morshita et al. (1989) reported increase in fish muscle lipid values in cultured seabream with increase in size of fish. However, Giogios et al. (2013) in farmed Argyrosomus regius known for very low fillet lipid content, reported that bigger sized fish (1600 g) contained lower total lipid than smaller ones $(830 \mathrm{~g})$ and authors attributed this to a different lipid metabolism (Grigorakis et al., 2011) of the fish and the feed offered to the fish while farming. The crude protein values were lower in farmed fish in the present study and this finding is in agreement with the earlier reports in channel catfish (Nettleton and Exler, 1992).

The saturated (SFA), monounsaturated (MUFA) and polyunsaturated fatty acid (PUFA) profiles of L. parsia from different systems and size groups are shown in Table 3, 4 and 5, respectively. The major fatty acids identified in both wild and farmed fish were C16:0 (palmitic), C18:0 (stearic), C18:1n-9 (oleic), C18:2 n-6 (linoleic), C20:5n-3 (eicosapentaenoic acid, EPA) and C22:6n-3 (docosahexaenoic acid, DHA). Cultured L. parsia contained significantly $(\mathrm{p}<0.05)$ higher levels of almost all the fatty acids except C18:3n-3 (linolenic) and C20:4n-6 (arachidonic). The C16:0 was predominant of all the other fatty acids in both cultured and wild
L. parsia. The levels of C16:0 and C18:0 in cultured fish were higher $(\mathrm{p}<0.05)$ by four and two folds respectively than in wild L. parsia. Among the MUFA, the contents of $\mathrm{C} 18: 1$ and C16:1 were predominant and these levels were also higher in cultured fish. Fatty acids like C18:2n-6 (LA), C20:5n-3 (EPA), C22: 6n-3 (DHA) and C20: 4n-6 (AA) were predominant among the PUFA. The levels of LA were significantly $(p<0.05)$ higher by more than 12 times in farmed fish. This multifold level of C16:0, C18:0 and C18:2n-6 fatty acids in cultured L. parsia may be attributed to the dominance of these fatty acids in the feed (Table 1). Similar dietary influence on fatty acid profiles of several farmed fishes have been reported (KrajnovicOzretic et al., 1994; Grigorakis et al., 2002; Fuentes et al., 2010). Very high accumulation (12 times) of C18:2n-6 in the cultured fish could be due to the reduced capacity for chain elongation and desaturation (KrajnovicOzretic et al., 1994; Morshita et al., 1989). L. parsia, on the other hand, had higher amounts (nearly double) of C20:4n-6, which is in agreement with the findings of Alasalvar et al. (2002) and Grigorakis et al. (2002).

Among the n-3 PUFA, EPA and DHA were the predominant fatty acids in both wild and farmed $L$. parsia. The contents of EPA $(\mathrm{p}>0.05)$ and DHA $(\mathrm{p}<0.05)$ were higher in cultured L. parsia. Similar to our results, higher contents of EPA and DHA (g $100 \mathrm{~g}^{-1}$ ) were also observed in cultured halibut fish compared to their wild samples (Olsson et al., 2003). Wide variations were reported in the 
Table 3. Saturated fatty acid (SFA) composition (mg $100 \mathrm{~g}^{-1}$ fish) of different size groups of $L$. parsia collected from wild and captivity

\begin{tabular}{|c|c|c|c|c|c|c|c|}
\hline \multirow{2}{*}{ Particulars } & \multicolumn{7}{|c|}{ Saturated fatty acids (SFA) } \\
\hline & C14:0 & C15:0 & C16:0 & C17:0 & C18:0 & $\mathrm{C} 21: 0$ & C23:0 \\
\hline \multicolumn{8}{|l|}{ Source } \\
\hline Cultured & $119.85^{\mathrm{a}} \pm 20.15$ & $26.22^{\mathrm{a}} \pm 4.14$ & $1512.86^{\mathrm{a}} \pm 239.24$ & $32.06 \pm 4.77$ & $447.43^{a} \pm 97.92$ & $3.42^{\mathrm{a}} \pm 0.89$ & $43.58^{\mathrm{a}} \pm 5.71$ \\
\hline Wild & $55.11^{\mathrm{b}} \pm 10.71$ & $9.62^{b} \pm 1.37$ & $376.76^{\mathrm{b}} \pm 52.19$ & $30.54 \pm 3.86$ & $187.81^{b} \pm 32.06$ & $0.74^{b} \pm 0.13$ & $38.18^{b} \pm 5.74$ \\
\hline \multicolumn{8}{|l|}{ Size group $(\mathrm{g})$} \\
\hline$<50$ & $32.85^{\mathrm{d}} \pm 7.85$ & $7.77^{\mathrm{d}} \pm 2.08$ & $436.63^{d} \pm 131.75$ & $14.32^{\mathrm{d}} \pm 1.37$ & $100.95^{\mathrm{c}} \pm 22.28$ & $0.42^{\mathrm{c}} \pm 0.14$ & $18.08^{\mathrm{d}} \pm 3.37$ \\
\hline $50-100$ & $58.84^{c} \pm 12.98$ & $12.27^{\circ} \pm 2.76$ & $596.22^{\mathrm{c}} \pm 161.34$ & $24.16^{\mathrm{c}} \pm 1.67$ & $154.77^{\mathrm{c}} \pm 21.31$ & $1.28^{\mathrm{bc}} \pm 0.38$ & $34.06^{c} \pm 4.54$ \\
\hline $101-150$ & $92.09^{b} \pm 20.27$ & $20.54^{b} \pm 4.74$ & $1092.63^{b} \pm 315.61$ & $35.77^{\mathrm{b}} \pm 2.38$ & $391.57^{b} \pm 98.12$ & $2.05^{\mathrm{b}} \pm 0.59$ & $42.45^{b} \pm 2.09$ \\
\hline$>150$ & $166.16^{\mathrm{a}} \pm 24.18$ & $31.09^{\mathrm{a}} \pm 6.74$ & $1653.76^{\mathrm{a}} \pm 452.83$ & $50.95^{\mathrm{a}} \pm 2.62$ & $623.19^{\mathrm{a}} \pm 124.52$ & $4.56^{\mathrm{a}} \pm 1.62$ & $68.93^{\mathrm{a}} \pm 2.54$ \\
\hline \multicolumn{8}{|c|}{ Source x Size $(\mathrm{g})$ interactions } \\
\hline Cultured $\mathrm{x}<50$ & $46.19^{\mathrm{e}} \pm 11.39$ & $11.35^{\mathrm{d}} \pm 2.94$ & $688.00^{\mathrm{d}} \pm 153.51$ & $14.06^{\mathrm{f}} \pm 2.91$ & $133.80^{\mathrm{de}} \pm 37.36$ & $0.61^{\mathrm{cd}} \pm 0.24$ & $22.39 \pm 6.17$ \\
\hline Cultured x 50-100 & $77.18^{\mathrm{d}} \pm 3.15$ & $16.36^{\mathrm{c}} \pm 0.93$ & $903.12^{c} \pm 35.93$ & $20.90^{\mathrm{de}} \pm 1.73$ & $152.27^{d} \pm 22.16$ & $1.92^{\mathrm{bc}} \pm 0.11$ & $33.77 \pm 1.76$ \\
\hline Cultured $\mathrm{x}<101-150$ & $136.63^{\mathrm{b}} \pm 8.17$ & $31.12^{b} \pm 0.29$ & $1796.62^{b} \pm 38.98$ & $39.96^{b} \pm 2.83$ & $610.07^{b} \pm 17.40$ & $3.29^{b} \pm 0.45$ & $46.36 \pm 1.25$ \\
\hline Cultured $x>150$ & $219.41^{a} \pm 2.85$ & $46.04^{a} \pm 0.67$ & $2663.69^{\mathrm{a}} \pm 65.13$ & $53.29^{\mathrm{a}} \pm 0.93$ & $893.58^{\mathrm{a}} \pm 57.02$ & $7.88^{\mathrm{a}} \pm 1.43$ & $71.81 \pm 0.99$ \\
\hline Wild $x<50$ & $19.50^{\mathrm{f}} \pm 0.70$ & $4.19^{\mathrm{e}} \pm 0.22$ & $185.26^{\mathrm{f}} \pm 5.61$ & $14.57^{\mathrm{ef}} \pm 0.96$ & $68.10^{\mathrm{e}} \pm 2.84$ & $0.23^{\mathrm{d}} \pm 0.07$ & $13.77 \pm 0.34$ \\
\hline Wild x 50-100 & $40.49^{e} \pm 1.06$ & $8.18^{\mathrm{de}} \pm 0.56$ & $289.31^{\mathrm{ef}} \pm 3.12$ & $27.41^{\mathrm{cd}} \pm 0.80$ & $157.27^{\mathrm{d}} \pm 0.78$ & $0.64^{\mathrm{cd}} \pm 0.13$ & $34.35 \pm 1.36$ \\
\hline Wild $\mathrm{x}<101-150$ & $47.55^{\mathrm{e}} \pm 2.26$ & $9.96^{\mathrm{d}} \pm 0.64$ & $388.65^{\mathrm{e}} \pm 30.54$ & $31.58^{c} \pm 1.65$ & $173.06^{\mathrm{d}} \pm 9.63$ & $0.82^{\mathrm{cd}} \pm 0.21$ & $38.54 \pm 2.25$ \\
\hline Wild $x>150$ & $112.90^{c} \pm 8.84$ & $16.15^{\mathrm{c}} \pm 1.90$ & $643.82^{\mathrm{d}} \pm 32.57$ & $48.61^{\mathrm{a}} \pm 5.29$ & $352.80^{c} \pm 34.09$ & $1.24^{\mathrm{cd}} \pm 0.26$ & $66.05 \pm 4.80$ \\
\hline
\end{tabular}

All values are mean $\pm \mathrm{SE}$ of three replications

Means bearing same superscripts in a column within the category do not differ significantly $(\mathrm{p}>0.05)$

Table 4. Monounsaturated fatty acid (MUFA) composition (mg $100 \mathrm{~g}^{-1}$ fish) of different size groups of L. parsia collected from wild and captivity

\begin{tabular}{|c|c|c|c|c|c|c|}
\hline \multirow{2}{*}{ Particulars } & \multicolumn{6}{|c|}{ Monounsaturated fatty acids (MUFA) } \\
\hline & $\mathrm{C} 14: 1$ & C16:1 & $\mathrm{C} 17: 1$ & $\mathrm{C} 18: 1 \mathrm{c}$ & $\mathrm{C} 18: 1 \mathrm{t}$ & $\mathrm{C} 22: 1$ \\
\hline \multicolumn{7}{|l|}{ Source } \\
\hline Cultured & $2.21^{\mathrm{a}} \pm 0.55$ & $568.20^{\mathrm{a}} \pm 91.42$ & $39.81^{\mathrm{a}} \pm 7.51$ & $693.41^{\mathrm{a}} \pm 100.97$ & $15.83 \pm 2.53$ & $3.64^{b} \pm 0.71$ \\
\hline Wild & $0.79^{b} \pm 0.13$ & $230.56^{\mathrm{b}} \pm 45.45$ & $18.13^{b} \pm 2.70$ & $83.84^{\mathrm{b}} \pm 13.12$ & $13.22 \pm 1.83$ & $6.67^{\mathrm{a}} \pm 1.07$ \\
\hline \multicolumn{7}{|l|}{ Size group $(g)$} \\
\hline$<50$ & $0.55^{\mathrm{c}} \pm 0.14$ & $182.79^{c} \pm 56.90$ & $11.52^{\mathrm{d}} \pm 2.51$ & $171.24^{\mathrm{d}} \pm 72.75$ & $5.78^{c} \pm 0.97$ & $1.86^{\mathrm{c}} \pm 0.19$ \\
\hline $50-100$ & $0.84^{\mathrm{bc}} \pm 0.22$ & $251.31^{\mathrm{c}} \pm 58.59$ & $19.23^{c} \pm 3.16$ & $286.76^{c} \pm 106.60$ & $12.34^{\mathrm{b}} \pm 1.94$ & $3.96^{\mathrm{b}} \pm 0.14$ \\
\hline $101-150$ & $1.61^{\mathrm{b}} \pm 0.40$ & $416.93^{b} \pm 97.72$ & $30.25^{b} \pm 6.32$ & $428.83^{\mathrm{b}} \pm 152.59$ & $15.80^{\mathrm{b}} \pm 1.27$ & $5.52^{\mathrm{b}} \pm 1.04$ \\
\hline$>150$ & $2.99^{\mathrm{a}} \pm 0.93$ & $746.49^{\mathrm{a}} \pm 127.97$ & $54.89^{\mathrm{a}} \pm 10.59$ & $667.69^{\mathrm{a}} \pm 233.30$ & $24.17^{\mathrm{a}} \pm 2.26$ & $9.27^{\mathrm{a}} \pm 1.18$ \\
\hline \multicolumn{7}{|c|}{ Source $\mathrm{x}$ Size $(\mathrm{g})$ interactions } \\
\hline Cultured $\mathrm{x}<50$ & $0.74^{\mathrm{c}} \pm 0.21$ & $286.41^{\mathrm{de}} \pm 73.61$ & $15.82^{\mathrm{d}} \pm 3.60$ & $313.50^{\mathrm{d}} \pm 78.89$ & $5.55 \pm 2.16$ & $1.57 \pm 0.28$ \\
\hline Cultured x 50-100 & $1.01^{\mathrm{c}} \pm 0.34$ & $335.97^{d} \pm 25.39$ & $21.22^{\mathrm{d}} \pm 0.94$ & $503.46^{\mathrm{c}} \pm 23.00$ & $13.23 \pm 2.42$ & $2.19 \pm 0.27$ \\
\hline Cultured $\mathrm{x}<101-150$ & $2.37^{\mathrm{b}} \pm 0.47$ & $632.54^{\mathrm{b}} \pm 31.57$ & $44.06^{b} \pm 2.95$ & $769.12^{\mathrm{b}} \pm 24.06$ & $17.82 \pm 1.95$ & $3.66 \pm 1.05$ \\
\hline Cultured $x>150$ & $4.71^{\mathrm{a}} \pm 1.12$ & $1017.88^{\mathrm{a}} \pm 83.54$ & $78.14^{a} \pm 3.64$ & $1187.58^{\mathrm{a}} \pm 42.09$ & $26.70 \pm 3.08$ & $7.12 \pm 0.72$ \\
\hline Wild $x<50$ & $0.36^{\mathrm{c}} \pm 0.12$ & $79.16^{\mathrm{f}} \pm 5.48$ & $7.22^{\mathrm{e}} \pm 0.14$ & $28.97^{\mathrm{f}} \pm 0.29$ & $6.01 \pm 0.13$ & $2.14 \pm 0.16$ \\
\hline Wild x 50-100 & $0.67^{\mathrm{c}} \pm 0.07$ & $166.64^{\mathrm{ef}} \pm 8.25$ & $17.23^{\mathrm{d}} \pm 0.64$ & $70.07^{\mathrm{ef}} \pm 0.53$ & $11.45 \pm 0.58$ & $5.73 \pm 0.63$ \\
\hline Wild $\mathrm{x}<101-150$ & $0.86^{c} \pm 0.12$ & $201.33^{\mathrm{ef}} \pm 16.32$ & $16.44^{\mathrm{d}} \pm 0.75$ & $88.55^{\mathrm{ef}} \pm 7.08$ & $13.77 \pm 0.29$ & $7.38 \pm 0.91$ \\
\hline Wild $x>150$ & $1.27^{\mathrm{bc}} \pm 0.32$ & $475.09^{c} \pm 35.28$ & $31.63^{c} \pm 2.62$ & $147.79^{\mathrm{e}} \pm 8.89$ & $21.63 \pm 3.12$ & $11.43 \pm 1.34$ \\
\hline
\end{tabular}

All values are mean \pm SE of three replications

Means bearing same superscripts in a column within the category do not differ significantly $(\mathrm{p}>0.05)$

quantities of EPA and DHA in seafood, 2.7 - 2041 and

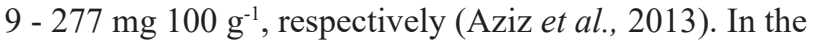
present study, the total EPA and DHA was also higher in farmed fish i.e., 253 and $411 \mathrm{mg} 100 \mathrm{~g}^{-1}$ in 101-150 size

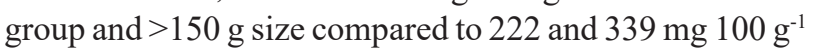

in wild caught mullets of similar size groups, respectively (Fig. 1). The highest concentration of EPA and DHA (1804 mg $100 \mathrm{~g}^{-1}$ ) was observed in farmed trout (Usydus et al., 2011), which were fed mainly on diets containing a higher level of fishmeal and fish oil. Huynh and Kitts 


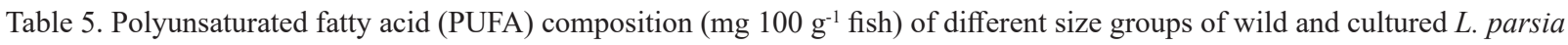

\begin{tabular}{|c|c|c|c|c|c|c|c|}
\hline \multirow{2}{*}{ Particulars } & \multicolumn{7}{|c|}{ Polyunsaturated fatty acids (PUFA) } \\
\hline & $\mathrm{C} 18 \mathrm{ac}$ & $\gamma \mathrm{C} 18: 3$ & $\alpha \mathrm{C} 18: 3$ & $\mathrm{C} 20: 4$ & $\mathrm{C} 20: 5$ & $\mathrm{C} 22: 2$ & $\mathrm{C} 22: 6$ \\
\hline \multicolumn{8}{|l|}{ Source } \\
\hline Cultured & $429.29^{\mathrm{a}} \pm 65.37$ & $32.05^{\mathrm{a}} \pm 5.35$ & $16.74^{b} \pm 2.75$ & $55.89^{b} \pm 9.46$ & $110.59 \pm 20.47$ & $14.01 \pm 2.83$ & $108.60^{\mathrm{a}} \pm 19.69$ \\
\hline Wild & $33.29 \pm 5.50$ & $18.26^{b} \pm 2.55$ & $59.53^{a} \pm 10.48$ & $133.82^{\mathrm{a}} \pm 19.68$ & $115.03 \pm 16.77$ & $16.67 \pm 2.30$ & $89.90^{b} \pm 11.40$ \\
\hline \multicolumn{8}{|l|}{ Size groups (g) } \\
\hline$<50$ & $99.38^{\mathrm{d}} \pm 45.52$ & $10.28^{\mathrm{d}} \pm 1.72$ & $16.01^{\mathrm{c}} \pm 3.86$ & $36.16^{\mathrm{c}} \pm 6.31$ & $48.25^{\mathrm{d}} \pm 5.37$ & $6.38^{c} \pm 0.96$ & $43.70^{\mathrm{d}} \pm 6.44$ \\
\hline $50-100$ & $167.27^{\mathrm{c}} \pm 66.71$ & $18.65^{\mathrm{c}} \pm 2.65$ & $30.41^{b} \pm 3.04$ & $88.80^{b} \pm 3.85$ & $79.81^{\mathrm{c}} \pm 3.22$ & $11.69^{b} \pm 0.28$ & $63.39^{c} \pm 3.48$ \\
\hline $101-150$ & $254.02^{b} \pm 97.89$ & $28.41^{\mathrm{b}} \pm 5.56$ & $33.51^{\mathrm{b}} \pm 7.67$ & $90.47^{b} \pm 11.20$ & $119.85^{\mathrm{b}} \pm 5.00$ & $15.79^{\mathrm{b}} \pm 0.61$ & $118.03^{b} \pm 6.23$ \\
\hline$>150$ & $404.48^{z} \pm 155.72$ & $43.29^{\mathrm{a}} \pm 6.10$ & $72.60^{a} \pm 19.49$ & $163.98^{\mathrm{a}} \pm 28.71$ & $203.33^{\mathrm{a}} \pm 16.36$ & $27.51^{\mathrm{a}} \pm 2.62$ & $171.90^{\mathrm{a}} \pm 15.55$ \\
\hline \multicolumn{8}{|c|}{ Source x Size $(\mathrm{g})$ interactions } \\
\hline Cultured $\mathrm{x}<50$ & $188.26^{\mathrm{d}} \pm 49.61$ & $12.29^{\mathrm{ef}} \pm 3.27$ & $7.67^{e} \pm 2.26$ & $23.43^{\mathrm{f}} \pm 6.04$ & $48.59 \pm 11.99$ & $5.41 \pm 1.88$ & $47.94^{\mathrm{e}} \pm 13.66$ \\
\hline Cultured x $50-100$ & $308.26^{c} \pm 9.06$ & $19.80^{\mathrm{d}} \pm 1.36$ & $10.85^{\text {de }} \pm 0.88$ & $32.16^{\mathrm{ef}} \pm 1.79$ & $62.09 \pm 1.25$ & $7.75 \pm 0.52$ & $52.93^{\mathrm{e}} \pm 3.46$ \\
\hline Cultured $\mathrm{x}<101-150$ & $471.52^{b} \pm 24.55$ & $40.64^{b} \pm 1.57$ & $18.69^{\mathrm{cde}} \pm 0.86$ & $66.46^{\mathrm{d}} \pm 1.45$ & $124.96 \pm 7.74$ & $15.56 \pm 1.16$ & $128.58^{b} \pm 4.45$ \\
\hline Cultured $x>150$ & $749.12^{\mathrm{a}} \pm 49.54$ & $55.47^{\mathrm{a}} \pm 5.73$ & $29.75^{c} \pm 3.80$ & $101.49^{c} \pm 4.89$ & $206.71 \pm 34.50$ & $27.30 \pm 4.94$ & $204.95^{\mathrm{a}} \pm 8.99$ \\
\hline Wild $x<50$ & $10.50^{\mathrm{e}} \pm 0.43$ & $8.26^{\mathrm{f}} \pm 0.05$ & $24.35^{\mathrm{cd}} \pm 0.14$ & $48.89^{\mathrm{e}} \pm 0.92$ & $47.90 \pm 0.28$ & $7.34 \pm 0.31$ & $39.45^{\mathrm{e}} \pm 1.74$ \\
\hline Wild x 50-100 & $26.29^{\mathrm{e}} \pm 0.74$ & $17.51^{\mathrm{de}} \pm 0.81$ & $49.97^{b} \pm 0.86$ & $145.43^{b} \pm 11.41$ & $97.53 \pm 2.03$ & $15.62 \pm 0.29$ & $73.81^{\mathrm{d}} \pm 0.74$ \\
\hline Wild $\mathrm{x}<101-150$ & $36.51^{\mathrm{e}} \pm 2.61$ & $16.17^{\mathrm{de}} \pm 1.55$ & $48.34^{b} \pm 8.60$ & $114.49^{c} \pm 6.96$ & $114.75 \pm 6.24$ & $16.01 \pm 0.70$ & $107.49^{c} \pm 7.96$ \\
\hline Wild $x>150$ & $59.84^{e} \pm 3.92$ & $31.11^{\mathrm{c}} \pm 2.25$ & $115.45^{\mathrm{a}} \pm 7.05$ & $226.48^{\mathrm{a}} \pm 13.81$ & $199.95 \pm 11.65$ & $27.71 \pm 3.16$ & $138.85^{b} \pm 5.99$ \\
\hline
\end{tabular}

Values are mean $\pm \mathrm{SE}$ of three replications

Means bearing same superscripts in a column within the category do not differ significantly $(\mathrm{p}>0.05)$

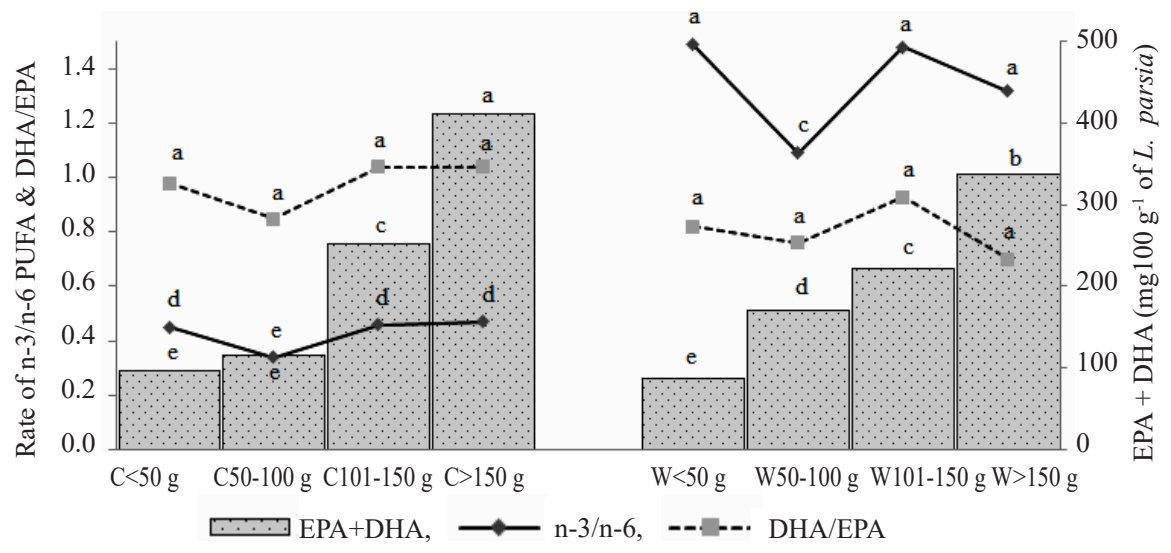

Fig. 1. EPA and DHA content (mg $100 \mathrm{~g}^{-1}$ fish), n-3/n-6 and DHA/EPA ratios in different size groups of L. parsia from wild and captivity. Means bearing the same alphabets for each nutrient do not differ significantly $(p>0.05)$

(2009) reported that Pacific herring (Clupea harengus pallasi) contained EPA and DHA at a much higher level of $1680 \mathrm{mg} 100 \mathrm{~g} \mathrm{~g}^{-1}$ tissue, attributing this to their planktonic filter feeding behaviour, as marine phytoplankton are the source of these long chain fatty acids. Significantly $(p<0.05)$ higher ratio of DHA/EPA was observed in cultured fish compared to wild fish. A similarly high DHA/EPA ratio was also observed in farmed halibut fish compared to their wild samples (Olsson et al., 2003), farmed sutchi cat fish and tilapia (Usydus et al., 2011). A higher ratio of DHA/EPA is a quality indicator of seafood. Whelen (2009) reported that DHA/EPA ratio has an advantageous impact on human health.

The contents of all the fatty acids increased $(p<0.05)$ in proportion to the size in both wild and farmed fish but the rate of increase was not uniform for all the fatty acids. The proportion of increase of SFA like C14:0 and C16:0 was higher between 101-150 g size in cultured fish, whereas a higher increase was observed at $>150 \mathrm{~g}$ size in wild fish. Similar variations in fatty acids in relation to increasing fish size were reported in gilthead sea bream 
(Benedito-Palos et al., 2011). The concentration of $n-6$ fatty acids especially C18:2n-6 increased proportionately with size in both wild and cultured $L$. parsia. Similarly, a higher content of 18:2n-6 and 20:4n-6 and total n-6 were also reported in larger meager fish $A$. regius (Giogios et $a l ., 2013)$. Kiessling and Kiessling (1993) suggested that the differences in the fatty acid profiles with respect to size could be due to the selective aerobic phosphorylation of fatty acids in the mitochondria of muscle tissue and the same was agreed by Froyland et al. (1998). The selective mobilisation of fatty acids to the reproductive organs in larger fish would also be a reason for the same (Perez et al., 2007).

The results obtained in the present study indicate that the recommended dose $\left(250 \mathrm{mg} \mathrm{day}^{-1}\right)$ of EPA and DHA (USDA \& USDHHS, 2010) could be obtained by consuming about $60,98,217$ and $259 \mathrm{~g}$ of cultured and $74,112,145$ and $286 \mathrm{~g}$ of captive L. parsia of $>150 \mathrm{~g}$, 101-150 g, 50-100 and $<50 \mathrm{~g}$ size groups, respectively. The n-3/n- 6 ratio of both wild and cultured $L$. parsia across all size groups were within the recommended level of 0.2 or above. However, the proportionate decrease of $n-3$ PUFA in farmed fish can be addressed by proper choice of dietary lipid sources that would allow the fatty acid composition of cultured L. parsia to be tailored to address the beneficial health aspects and consumer demands by keeping the cost effectiveness of feed formulations.

\section{Acknowledgements}

Authors express their sincere thanks to the Fisheries Division, Indian Council of Agricultural Research, New Delhi for supporting the ICAR-Outreach Activity on Nutrient Profiling and Evaluation of Fish as a Dietary Component. The support from Mr. T. Raghusekhar, a progressive Aqua-farmer for extending facilities to conduct culture experiments in his farm is also gratefully acknowledged.

\section{References}

Ackman, R. G. 1996. DHA: Can it benefit salmon marketing. J. Aquat. Food Prod. Technol., 5: 7-26. doi.org/10.1300/ J030v05n04 03.

Alasalvar, C., Taylor, K. D. A., Zubcov, E., Shahidi, F. and Alexis, M. 2002. Differentiation of cultured and wild seabass (Dicentrarchus labrax): total lipid content, fatty acid and trace mineral composition. Food Chem., 79: 145-150. DOI: 10.1016/S0308-8146(02)00122-X.

AOAC 1997. Official methods of analysis, $18^{\text {th }}$ edn. Association of Analytical Chemists, Benjamin Franklin Station, Washington DC, USA.

Aziz, N. A., Azlan, A., Ismail, A., Alinafiyah, S. M. and Razman, M. R. 2013. Quantitative determination of fatty acids in marine fish and shellfish from warm water of straits of Malacca for nutraceutical purposes. Bio-Med Res. Int., 1-12. doi.org/10.1155/2013/284329.

Benedito-Palos, L., Bermejo-Nogales, A., Karampatos, A. I., Ballester-Lozano, G. F., Navarro, J. C., Diez, A., Bautista, J. M., Bell, J. G., Tocher, D. R., Obach, A., Kaushik, S. and Perez-Sanchez, J. 2011. Modelling the predictable effects of dietary lipid sources on the fillet fatty acid composition of one year old gilthead seabream (Sparus aurata L.). Food Chem., 124: 538-544. DOI: 10.1016/j. foodchem.2010.06.066.

Berbert, A. A., Kondo, C. R., Almendra, C. L., Matsuo, T. and Dichi, I. 2005. Supplementation of fish oil and olive in patients with rheumatoid arthritis. Nutrition, 21: 131-136. DOI: 10.1016/j.nut.2004.03.023.

Calo, L., Bianconi, L., Colivicchi, F., Lamberti, F., Loricchio, M. L., de Ruvo, E., Meo, A., Pandozi, C., Staibano, M. and Santini, M. 2005. Fatty acids for the prevention of atrial fibrillation after coronary artery bypass surgery: A randomized, controlled trial. J. Am. Coll. Cardiol., 45: 1723-1728. DOI: 10.1016/j.jacc.2005.02.079.

Conor, W. E. 2000. Importance of n-3 fatty acids in health and diseases, Am. J. Clin. Nutr., 71: 171S-175S.

Dayal, J. S., Ambasankar, K., Jannathulla, R., Kumaraguruvasagam, K. P., Kailasam, M and Vijayan, K. K. 2017. Polyculture of mullets in brackishwater using compounded feed: proximate and mineral profiles in comparison with wild mullets. Indian J. Fish., 64: 50-57. DOI: 10.21077/ijf.20 17.64.4.69810-07.

FAO 2014. The state of world fisheries and aquaculture opportunities and challenges. Food and Agricultural Organisation of the United Nations, Rome. http://www.fao. org/publications (Accessed 06 May 2014).

Folch, J., Lees, M. and Sloane-Stanley, G. H. 1957 A simple method for the isolation and purification of total lipids from animal tissues. J. Biol. Chem., 226: 497- 509.

Froyland, L., Madsen, L., Eckhoff, K. M., Lie, O. and Berge R. 1998. Carnitine palmitoyltransferase I, carnitine palmitoyltranferase II, and acetyl CoA oxidase activities in Atlantic salmon (Salmo salar). Lipids, 33: 923-930.

Fuentes A., Fernández-Segovia, I., Serra, J. A. and Barat, J. M. 2010. Comparison of wild and cultured seabass (Dicentrarchus labrax) quality. Food Chem., 119: 1514-1518. DOI:10.1016/j.foodchem.2009.09.036.

George, R. and Bophal, R. 1995. Fat composition of free living and farmed sea species: implications for human diet and sea farming techniques. Br. Food J., 97: 19-22. DOI: $10.1108 / 00070709510100073$.

Giogios, I., Grigorakis, K. and Kalogeropoulos, N. 2013. Organoleptic and chemical quality of farmed meagre (Argyrosomus regius) as affected by size. Food Chem., 14: 3153-3159. DOI: 10.1016/j.foodchem.2013.05.154. 
Grigorakis, K., Alexis, M. N., Taylor, K. D. A. and Hole, M. 2002. Comparison of wild and cultured gilthead sea bream (Sparus aurata): composition, appearance and seasonal variations. Int. J. Food Sci. Tech., 37: 477-484. DOI: $10.1046 / j .1365-2621.2002 .00604 . x$.

Grigorakis, K. and Alexis, M. 2005. Effects of fasting on the meat quality and fat deposition of commercial-size farmed gilthead sea bream (Sparus aurata L.) fed different dietary regimes. Aquac. Nutr., 11: 341-344. doi.org/10.1111/j.13 65-2095.2005.00351.x.

Grigorakis, K. Fountoulaki, E., Vasilaki, A., Mittakos, I. and Nathanailides, C. 2011. Lipid quality and filleting yield of reared meager (Argyrosomus regius). Int. J. Food Sci. Technol., 46: 711-716. DOI: 10.1111/j.1365-2621.2010. 02537.x.

Haard, N. F. 1992. Control of chemical composition and food quality attributes of cultured fish. Food Res. Int., 25: 289-307. DOI: 10.1016/0963-9969(92)90126-P.

Karakoltsidis, P. A., Zotos, A. and Contantindes, S. M. 1995. Composition of the commercially important Mediterranean finfish, crustaceans and molluscs. J. Food Comp. Anal., 8: 258-273.

Kiessling, K. H. and Kiessling, A 1993. Selective utilization of fatty acids in rainbow trout (Oncorhynchus mykiss Walbaum) red muscle mitochondria. Can. J. Zool., 71: 248-251.

Krajnovic-Ozretic, M., Najdek, M. and Ozretic, B. 1994. Fatty acid in liver and muscle of farmed and wild seabass (Dicentrarchus labrax L.). Comp. Biochem. Physiol., 109A: 611-617. doi.org/10.1016/0300-9629(94)90200-3

Marais, J. F. K. and Erasmus, T. 1977. Body composition of Mugil cephalus, Liza dumerili, Liza richardsoni and Liza tricuspidens (Teleostei; Mugilidae) caught in the Swartkops Estuary. Aquaculture, 10: 75-86. doi.org/10.1016/00448486(77)90034-5.

Menezes, M. E. S., Lira, G. M., Omena, C. M. B., Freitas, J. D. and Sant'Ana, A. E. G. 2008. Proximate composition, cholesterol and fatty acid of the fished species of estuarino Tainha (Mugil cephalus) and Camurim (Centropomus undecimalis) from Mundaú Lagoon, A1/Brazil. Rev. Inst. Adolfo Lutz, 67: 89-95.

Metcalfe, L. D., Schimitz, A. A. and Pelka, J. R. 1966. Rapid preparation of fatty acids esters from lipids for gas chromatographic analysis. Annexe Chem., 38: 524-535.

Morshita, T., Uno, K., Araki, T. and Takahashi, T. 1989. Comparision of the fatty acid compositions in cultured Red seabream differing in the localities and culture methods; and those in wild fish. Nippon Suisan Gakk., 55: 847-852.

Nash, C. E. and Shehadeh, Z. H. 1980. Review of breeding and propagation techniques for grey mullet, Mugil cephalus L. In: ICLARM Studies and Reviews. International Center for Living Aquatic Resources Management, Manila, Philippines, p. 3-87.

Nettleton, J. A. and Exler, J. 1992. Nutrients in wild and farmed fish and shellfish. J. Food Sci., 57: 257-260. doi. org/10.1111/j.1365-2621.1992.tb05470.x.

Olsson, G. B., Ragnar, L., Carleho, O. M. and Ofstad, R. 2003. Seasonal variations in chemical and sensory characteristics of farmed and wild Atlantic halibut (Hippoglossus hippoglossus). Aquaculture, 217: 191-205. doi.org/10.1016/S0044-8486(02)00191-6.

Paul, B. N., Chandra S., Das, S., Sridhar, N., Saha, G. S. and Giri, S. S. 2015. Seasonal varation in proximate and mineral composition of Koi Anabas testudineus, Bloch 1792. Anim. Nutr. Feed Technol.,15: 465-470.

Perez, M. J., Rodriguez, C., Cejas, J. R., Martin, M. V., Jerez, S. and Lorenzo, A. 2007. Lipid and fatty acid content in wild white seabream (Diplodus sargus) broodstock at different stages of the reproductive cycle. Comp. Biochem. Physiol., 146: 187-196. DOI: 10.1016/j.cbpb.2006.10.097.

Poli, B. M., Parisi, G., Zampacavallo, G., Mecatti, M., Lupi, P., Gualtieri, M. and Franci, O. 2001. Quality outline of European seabass (Dicentrarchus labrax) reared in Italy: shelf life, edible yield, nutritional and dietetic traits. Aquaculture, 202: 303-315. DOI: 10.1016/S00448486(01)00780-3.

Ramírez, J. A., Rodríguez-Sosa, R., Morales, O. G. and Vàzquez, M. 2003. Preparation of surimi gels from striped mullet (Mugil cephalus) using an optimal level of calcium chloride. Food Chem., 82: 417-423. DOI: 10.1016/S03088146(02)00594-0.

Rheman, S., Islam, M. L., Shah, M. M. R., Mondal, S. and Alam, M. J. 2002. Observation on the fecundity and gonadosomatic index (GSI) of grey mullet Liza parsia (Ham.). J. Biol. Sci., 2: 690-693. DOI: 10.3923/jbs.2002.690.693.

USDA \& USDHHS 2010. Dietary Guidelines for Americans, $7^{\text {th }}$ edn. December 2010, United States Department of Agriculture and United States Department of Health and Human Services. US Government Printing Office, Washington DC, USA.

USDHHS 2015. Dietary Guidelines or Americans 2015 $2020,8^{\text {th }}$ edn. United States Department of Health and Human Services, Washington, DC. www.health.gov/ dietaryguidelines/20115/guidelines (Accessed 18 April 2016).

Usydus, Z. J., Szlinder-Richert, Adamczyk, M. and Szatkowska, U. 2011. Marine and farmed fish in the Polish market: Comp. Nutr. Value Food Chem., 126: 78-84. DOI10.1016/j. foodchem.2010.10.080.

Whelen, J. 2009. Fishy business: Aquaculture, omega-3 fatty acids and health. Aquaculture America, Washington, USA. 
Wolk, A., Larsson, S. C., Johansson, J. E. and Ekman, P. 2006. Long-term fatty fish consumption and renal cell carcinoma incidence in a population-based prospective cohort of women. J. Am. Med. Ass., 296: 1371-1376.
Zhao, F., Zhuang, P., Song, C., Shi, Z. and Zhang, L. 2010. Amino acid and fatty acid compositions and nutritional quality of muscle in the pomfret, Pampus punctatissimus. Food Chem., 118: 224-227. DOI: 10.1016/j.foodchem.2009.04.110.

Date of Receipt $\quad$ : 19.11.2018

Date of Acceptance : 26.03.2019 